\title{
Gambaran Eritrosit Ayam Broiler Dengan Waktu Tempuh Transportasi dan Level Pemberian $\mathrm{ZnSO}_{4}$ Berbeda
}

\author{
Erithrocyte Profile of Broiler Chicken with Different Transport Time and Level of $\mathrm{ZnSO}_{4}$ Given \\ E. D. Parwati ${ }^{*}$, N. Ulupi ${ }^{1}$, R. Afnan ${ }^{1}$, A. S. Satyaningtijas ${ }^{2}$ \\ ${ }^{1}$ Departemen Ilmu Produksi dan Teknologi Peternakan, Fakultas Peternakan, \\ Institut Pertanian Bogor, Bogor, 16680 \\ ${ }^{2}$ Departemen Anatomi, Fisiologi, dan Farmakologi, Fakultas Kedokteran Hewan, \\ Insitut Pertanian Bogor, Bogor 16680 \\ E-mail: endahdiaah@gmail.com
}

\begin{abstract}
Transportation of broiler chickens in Indonesia from cage to traditional slaughterhouse has the potential to cause stress because it does not heed the elements of animal welfare. Thus, this study aims to examine the impact of transport time to hematological value with $\mathrm{ZnSO}_{4}$ given in broiler chickens. The research design used was Randomized Block Design (RAK) of factorial with two treatment factors. Treatment factors are transport time (1, 2, and 3 hours) and supplementation of $\mathrm{ZnSO}_{4}(0,80$, and $160 \mathrm{ppm})$. Total of 144 male broiler chickens aged 4 weeks were the object of observation. Transportation performed in the early morning. Parameters studied were hematology value which are consists of erythrocyte count, hemoglobin level, hematocrit value, and erythrocyte index. The data analysis was done statistically using IBM SPSS version 20. Transport time proved to affect hematological value of birds seen from the changes, which are decrease of erythrocyte count and hematocrit values. Birds were indicated microcytic anemia based on low MCV value. Supplementation of $\mathrm{ZnSO}_{4}$ through drinking water at 80 and $160 \mathrm{ppm}$ for 7 days prior to slaughter was able to maintain hemoglobin and $\mathrm{MCH}$ as well as MCHC of birds up to 2 hours of transport time.
\end{abstract}

Keywords: broiler chicken, stress, transport time, Zn

\section{PENDAHULUAN}

Panas yang dikeluarkan dari tubuh ternak berpotensi meningkatkan suhu di dalam keranjang angkut selama transportasi berlangsung dan mengakibatkan stres. Stres berakibat kepada perubahan status hematologi ayam serta mengganggu sistem pertahanan tubuh (Nain et al. 2008). Komponen darah secara khusus sangat sensitif terhadap perubahan dari suhu lingkungan sehingga menjadi indikator penting dalam respon fisiologis pada ayam (Tawfeek et al. 2014). Sel darah merah (eritrosit) merupakan komponen terbesar dalam darah yang memiliki peranan penting dalam transportasi oksigen dan nutrisi yang dibutuhkan oleh tubuh. Transportasi ayam broiler berpotensi menyebabkan gejala stres, salah satunya dengan perubahan gambaran total eritrosit (Sturkie dan Griminger 1976).

Zn memiliki peranan penting dalam sistem antioksidan pertahanan tubuh (Tawfeek et al. 2014). Sunder et al. (2012) menyatakan bahwa $\mathrm{Zn}$ organik pada level 60 dan 80 ppm secara umum dapat meningkatkan sinergisme terhadap bio-availability dan respon imun pada ayam broiler umur 35 hari. Penambahan mineral $\mathrm{ZnSO}_{4}$ melalui air minum pada level berbeda dilakukan untuk meminimalisir gejala stres yang mungkin terjadi pada ayam broiler akibat transportasi.

\section{MATERI DAN METODE}

\section{Materi}

Materi yang digunakan berupa ayam broiler jantan sejumlah 154 ekor berumur 4 minggu. Bahan pendukung penelitian antara lain pakan komersial, suplemen zinc sulfat $\left(\mathrm{ZnSO}_{4}\right)$, antikoagulan Ethylenediaminetetraacetic Acid (EDTA), larutan Rees \& Ecker, aquadestilata, $\mathrm{HCl} 0.1 \mathrm{~N}$, metanol absolut, zat warna Giemsa, larutan Phosphate Buffer Saline (PBS), metil alkohol, dan alkohol 70\%.

Alat bantu pengamatan di laboratorium antara lain lancet, cover glass, heparinized microcapillary tube, centrifuge mikrokapiler, microcapillary reader, crestaseal, Hemositometer Neubauer, spektrofotometer, GlucoDr ${ }^{\mathrm{TM}}$, Mission ${ }^{\circledR}$ Ultra Cholesterol Test. Peralatan yang digunakan antara lain keranjang angkut $(85 \times 65 \mathrm{~cm})$, kandang sistem litter, wadah ransum dan air minum, alat transportasi, syringe $3 \mathrm{ml}$, termohigrometer, peralatan laboratorium, dan peralatan pembersih kandang.

Pemeliharaan

Total ayam yang dipelihara sebanyak 144 ekor dengan 54 ekor yang menjadi objek pengamatan. Ayam 
broiler dipelihara hingga berumur 4 minggu dan pada minggu kelima diberikan $\mathrm{ZnSO}_{4}$ melalui air minum. Satu jam setelah pemberian pakan pada pagi hari, ternak diberi air minum yang telah dicampur dengan $\mathrm{ZnSO}_{4}$. Setelah larutan tersebut habis, ternak diberi air minum biasa ad libitum. Pola pemberian pakan tidak mengalami perubahan selama pemberian $\mathrm{ZnSO}_{4}$.

\section{Transportasi}

Transportasi ayam broiler menuju RPHU dilakukan menggunakan kendaraan roda 4 bak terbuka. Ayam broiler dimasukkan ke dalam keranjang angkut sebanyak 12 ekor per keranjang. Waktu transportasi dilakukan pukul 02.0005.00 WIB dengan 3 waktu tempuh berbeda yaitu 1, 2, dan 3 jam dengan kecepatan konstan $40 \mathrm{~km} / \mathrm{jam}$. Setelah proses transportasi selesai, keranjang angkut diturunkan dan ayam diistirahatkan selama 30 menit sebelum dilakukan proses pemotongan.

\section{Pengambilan Sampel}

Sampel darah diambil sebanyak 2 kali, sesaat sebelum dan setelah proses transportasi disesuaikan dengan waktu tempuh perjalanan. Darah diambil dari pembuluh vena brachialis yang berada di bagian bawah sayap menggunakan syringe $3 \mathrm{ml}$. Darah disimpan di dalam tabung berisi koagulan EDTA dan dihomogenkan secara perlahan. Sampel disimpan sementara di dalam cooler box hingga dilakukan pengujian di laboratorium.

\section{Prosedur Pengujian Sampel}

\section{Jumlah eritrosit (Sastradipraja et al. 1989)}

Prinsip pengujian jumlah eristrosit adalah mengetahui banyaknya butir eritrosit. Darah dicampur dengan larutan pengencer menggunakan pipet eritrosit. Banyaknya butir darah per $\mathrm{mm}^{3}$ dihitung dibawah mikroskop menggunakan Hemositometer (kamar hitung). Jumlah eritrosit per $\mathrm{mm}^{3}$ darah dapat ditentukan setelah dilakukan nilai koreksi terhadap faktor pengenceran.

Kamar hitung disiapkan dan dibersihkan dengan kain yang bersih dan lunak. Darah diisap hingga angka 0,5 menggunakan aspirator pada pipet eritrosit kemudian larutan Rees \& Ecker hingga angka 101 yang tertera pada pipet. Campuran tersebut dihomogenkan dengan gerakan angka 8 sambil menutup kedua ujung pipet dengan ibu jari dan telunjuk. Setetes cairan dimasukkan ke dalam kamar hitung sebanyak 5 kotak dengan volume total $1 / 50 \mathrm{~mm}^{3}$ dengan cara menempelkan ujung pipet di antara dasar kamar hitung dengan kaca penutup. Jumlah total konsentrasi eritrosit dapat diketahui dengan menghitung faktor koreksi pengenceran sejumlah 200x.

\section{Nilai hematokrit (metode Mikrohematokrit)}

Prinsip pengujian nilai hematokrit adalah darah bercampur dengan antikoagulan diputar dengan alat centrifuge sehingga terbentuk lapisan-lapisan. Kolom atau lapisan yang terdiri atas butir-butir eritrosit atau eritrosit diukur dan dinyatakan sebagai \% volume dari keseluruhan darah.

Pengujian terhadap nilai hematokrit dilakukan dengan memasukkan sampel darah yang akan diuji ke dalam pipa kapiler sebanyak 4/5 bagian sementara ujung dari pipa mikrokapiler tersebut disumbat dengan crestaseal. Pipa kapiler kemudian disentrifugasi selama \pm 5 menit pada kecepatan $12000 \mathrm{rpm}$ sehingga terbentuk lapisan plasma darah, lapisan putih abu-abu (trombosit dan leukosit) dan lapisan merah (eritrosit). Nilai hematokrit dapat diketahui dengan mengukur persentase volume eritrosit dengan alat mikrohematokrit reader (Sastradipraja et al. 1989).

\section{Kadar hemoglobin (metode Sianmethemoglobin)}

Prinsip pengujian kadar hemoglobin adalah darah ditambahkan ke dalam suatu larutan yang mengandung kalium sianida dan kalium ferisianida (reagen Drabkins). Ferisianida akan merubah besi dari hemoglobin yang bervalensi dua $(++$ : ferro) menjadi bervalensi tiga $(+++$ : ferri) sehingga terbentuk methemoglobin dan berikatan dengan kalium sianida membentuk pigmen yang stabil ialah sianmethemoglobin. Intensitas warna campuran ini diukur menggunakan spektrofotometer pada panjang gelombang $540 \mathrm{~nm}$.

Reagen Drabkins diambil dengan pipet sebanyak 5,0 $\mathrm{ml}$ dan dimasukkan ke dalam tabung reaksi 1 dan 2 . Sebanyak 0,02 $\mathrm{ml}$ darah ditambahkan ke dalam tabung reaksi ke-2 dengan pipet Sahli dan dibilas sehingga tidak ada darah yang tertinggal. Larutan dicampurkan di dalam tabung dan didiamkan minimal 10 menit pada suhu kamar agar terbentuk sianmethemoglobin dengan baik. Pembacaan transmittance larutan dilakukan menggunakan spektrofotometer (Sastradipraja et al. 1989).

Indeks eritrosit (Sastradipraja et al. 1989)

Prinsip pengujian indeks eritrosit adalah untuk mengetahui status anemia yang diakibatkan oleh penurunan sel eritrosit di dalam tubuh. Pengamatan terhadap indeks eritrosit meliputi Mean Corpuscular Volume (MCV), Mean Corpuscular Hemoglobin Concentration (MCHC), dan Mean Cospuscular Hemoglobin (MCH). Pengamatan terhadap indeks eritrosit dapat dilakukan apabila kadar hemoglobin, nilai hematokrit dan jumlah eritrosit telah diketahui.

\section{Analisis Data}

Rancangan percobaan yang digunakan adalah Rancangan Acak Kelompok (RAK) pola faktorial dengan dua faktor perlakuan. Faktor perlakuan pertama adalah waktu tempuh dengan tiga taraf $(1,2$, dan 3 jam) dan faktor perlakuan kedua adalah level pemberian $\mathrm{ZnSO}_{4}$ dengan tiga taraf $(0,80$, dan $160 \mathrm{ppm})$. Sebagai kelompok adalah periode transportasi (hari 1, 2, dan 3). Pengujian data dilakukan dengan analisis ragam dan dilanjutkan dengan uji Duncan. Data yang diamati dalam penelitian ini adalah nilai selisih untuk setiap peubah.

\section{HASIL DAN PEMBAHASAN}

Pengambilan data dilakukan sekitar pukul 02.00 hingga 05.00 dini hari di lingkungan kampus Institut Pertanian Bogor. Transportasi berlangsung di wilayah Dramaga, Kabupaten Bogor dengan waktu tempuh 1, 2, dan 3 jam dengan kecepatan mobil konstan $40 \mathrm{~km} / \mathrm{jam}$. Suhu saat pengamatan berlangsung berkisar $24{ }^{\circ} \mathrm{C}-25{ }^{\circ} \mathrm{C}$ dengan kelembaban relatif (RH) 83\%-84\%. Suhu di dalam keranjang angkut selama proses transportasi berkisar $31{ }^{\circ} \mathrm{C}$.

\section{Gambaran Eritrosit}

Pengujian terhadap gambaran eritrosit meliputi 
selisih jumlah eritrosit, selisih kadar hemoglobin dan selisih nilai hematokrit. Hasil analisis disajikan dalam Tabel 1.

\section{Selisih Jumlah Eritrosit}

Setelah dilakukan analisis statistik terhadap selisih jumlah eritrosit, tidak ditemukan interaksi antara faktor lama waktu tempuh transportasi dengan faktor level pemberian $\mathrm{ZnSO}_{4}$ berbeda. Peubah selisih jumlah eritrosit tidak menunjukkan perbedaan pada ayam dengan waktu tempuh dan level pemberian $\mathrm{ZnSO}_{4}$ berbeda. Meski demikian, jumlah eritrosit ayam berada dalam kondisi normal baik pada sebelum transportasi $\left(2,69-2,96 \times 10^{6} / \mathrm{mm}^{3}\right)$ maupun setelah transportasi $\left(2,51-2,85 \times 10^{6} / \mathrm{mm}^{3}\right)$. Kisaran normal jumlah eritrosit ayam berkisar antara 2,5-3,9 x 106/ $\mathrm{mm}^{3}$ (Samour 2015).

Setelah transportasi, jumlah eritrosit pada sebagian besar kombinasi perlakuan mengalami penurunan kecuali pada kelompok ayam dengan pemberian $\mathrm{ZnSO}_{4}(80$ dan 160 ppm) setelah waktu tempuh 1 jam. Diduga bahwa sintesis eritrosit masih berlangsung pada ayam dengan pemberian $\mathrm{ZnSO}_{4} 80$ dan 160 ppm setelah transportasi 1 jam. Menurut Hoffbrand dan Petit (1996), sintesis eritrosit dipengaruhi oleh berbagai faktor, antara lain nutrisi berupa asam amino, vitamin, zat besi dan hormon eritropoietin. Diduga masih terdapat cadangan energi pada kedua kelompok ayam tersebut sehingga masih mampu mensintesis eritrosit.

Eritrosit berfungsi sebagai media pengangkut oksigen $\left(\mathrm{O}_{2}\right)$ dari paru-paru ke jaringan tubuh dan karbondioksida $\left(\mathrm{CO}_{2}\right)$ dari jaringan tubuh ke paru-paru oleh hemoglobin (Kementerian Kesehatan Republik Indonesia 2011). Sirkulasi udara di dalam keranjang angkut dapat terganggu akibat kepadatan tinggi dalam keranjang dan posisi peletakannya yang bertumpuk. Kebutuhan energi yang tidak tercukupi serta sirkulasi udara yang kurang baik memicu penurunan terhadap jumlah eritrosit ayam pada penelitian ini seiring lama waktu tempuh transportasi.

\section{Selisih Nilai Hematokrit}

Nilai hematokrit merupakan massa sel terbesar dalam darah dengan kisaran normal pada ayam yaitu $24 \%$ -
43\% (Virden et al. 2007; Samour 2015). Setelah dilakukan analisis statistik terhadap peubah selisih nilai hematokrit, tidak ditemukan interaksi antara lama waktu tempuh transportasi dengan level pemberian $\mathrm{ZnSO}_{4}$ berbeda. Peubah selisih nilai hematokrit tidak menunjukkan perbedaan pada ayam dengan waktu tempuh dan level pemberian $\mathrm{ZnSO}_{4}$ berbeda. Kondisi awal sebelum transportasi (1, 2, dan 3 jam), ayam broiler memiliki nilai hematokrit berkisar $23,01 \%-27,40 \%$.

Nilai hematokrit menandakan keberlangsungan transportasi oksigen dan nutrisi dalam darah (Etim et al. 2013). Setelah transportasi, selisih nilai hematokrit mengalami penurunan pada sebagian besar kombinasi perlakuan (22,94\%-27,30\%). Penurunan nilai hematokrit dapat menjadi indikasi terhadap penurunan kapasitas transportasi oksigen dalam darah (Wennecke 2004). Sirkulasi udara yang kurang baik di dalam keranjang angkut diduga memicu penurunan nilai hematokrit pada penelitian ini. Nilai hematokrit umumnya berbanding lurus dengan jumlah eritrosit (Virden et al. 2007). Hasil penelitian ini sesuai dengan pernyataan tersebut.

Penurunan tersebut merupakan indikasi ayam broiler telah mengalami fase kelelahan sebagai akibat stres transportasi. Tadich et al. (2005) menyatakan bahwa penurunan nilai hematokrit merupakan salah satu gejala stres transportasi pada ayam. Waktu tempuh hingga 3 jam dapat menyebabkan cekaman panas sebagai dampak dari kepadatan keranjang. Vo et al. (1978) menyatakan bahwa nilai hematokrit darah akan berkurang akibat paparan panas terhadap ayam. Hal tersebut menegaskan bahwa ayam telah berada dalam kondisi stres panas.

\section{Selisih Kadar Hemoglobin}

Hemoglobin dalam darah berperan sebagai pengikat oksigen sehingga umumnya berbanding lurus terhadap jumlah eritrosit. Kadar hemoglobin normal pada ayam berkisar antara 10,2-15,1 g/dL (Samour 2015). Setelah dilakukan analisis statistik, terdapat interaksi pada peubah selisih kadar hemoglobin terhadap lama waktu tempuh

Tabel 1. Gambaran eritrosit ayam broiler dengan waktu tempuh transportasi dan level pemberian $\mathrm{ZnSO}_{4}$ berbeda

\begin{tabular}{|c|c|c|c|c|c|c|c|c|c|c|c|}
\hline \multirow[t]{3}{*}{ Peubah } & \multirow{3}{*}{$\begin{array}{l}\mathrm{ZnSO}_{4} \\
(\mathrm{ppm})\end{array}$} & \multicolumn{9}{|c|}{ Waktu Tempuh } & \multirow{3}{*}{$\begin{array}{c}\text { Rataan } \\
\Delta\end{array}$} \\
\hline & & \multicolumn{3}{|c|}{$1 \mathrm{Jam}$} & \multicolumn{3}{|c|}{$2 \mathrm{Jam}$} & \multicolumn{3}{|c|}{$3 \mathrm{Jam}$} & \\
\hline & & $\mathrm{Sb}$ & St & $\Delta$ & $\mathrm{Sb}$ & St & $\Delta$ & $\mathrm{Sb}$ & St & $\Delta$ & \\
\hline \multirow{4}{*}{$\begin{array}{l}\text { Jumlah } \\
\text { Eritrosit } \\
(106 / \mathrm{mm} 3)\end{array}$} & 0 & $2,89 \pm 0,05$ & $2,84 \pm 0,05$ & $-0,06$ & $2,78 \pm 0,20$ & $2,59 \pm 0,26$ & $-0,2$ & $2,93 \pm 0,30$ & $2,81 \pm 0,45$ & $-0,13$ & $-0,13$ \\
\hline & 80 & $2,77 \pm 0,07$ & $2,84 \pm 0,17$ & 0,08 & $2,96 \pm 0,20$ & $2,85 \pm 0,17$ & $-0,11$ & $2,69 \pm 0,15$ & $2,6 \pm 0,13$ & $-0,08$ & $-0,04$ \\
\hline & 160 & $2,76 \pm 0,17$ & $2,84 \pm 0,18$ & 0,07 & $2,61 \pm 0,21$ & $2,51 \pm 0,41$ & $-0,1$ & $2,88 \pm 0,21$ & $2,83 \pm 0,03$ & $-0,05$ & $-0,03$ \\
\hline & Rataan & & & 0,03 & & & $-0,14$ & & & $-0,09$ & \\
\hline \multirow{4}{*}{$\begin{array}{l}\text { Hematokrit } \\
(\%)\end{array}$} & 0 & $26 \pm 1,50$ & $25,6 \pm 1,82$ & $-0,4$ & $26,22 \pm 0,77$ & $25,77 \pm 1,02$ & $-0,45$ & $26,27 \pm 5,02$ & $26,07 \pm 1,62$ & $-0,2$ & $-0,35$ \\
\hline & 80 & $27 \pm 0,80$ & $26,77 \pm 0,95$ & $-0,23$ & $26,43 \pm 0,93$ & $26,23 \pm 0,93$ & $-0,2$ & $23,77 \pm 2,35$ & $23,63 \pm 1,91$ & $-0,13$ & $-0,19$ \\
\hline & 160 & $24,73 \pm 2,50$ & $24,87 \pm 2,91$ & 0,13 & $27,4 \pm 2,15$ & $27,3 \pm 2,48$ & $-0,1$ & $23,01 \pm 0,49$ & $22,94 \pm 0,51$ & $-0,07$ & $-0,01$ \\
\hline & Rataan & & & $-0,17$ & & & $-0,25$ & & & $-0,13$ & \\
\hline \multirow{4}{*}{$\begin{array}{l}\text { Hemoglobin } \\
(\mathrm{g} / \mathrm{dL})\end{array}$} & 0 & $10,9 \pm 0,71$ & $10,58 \pm 0,57$ & $-0,31 \mathrm{a}$ & $9,77 \pm 0,64$ & $9,57 \pm 0,69$ & $-0,2 a$ & $10,94 \pm 0,63$ & $10,72 \pm 0,16$ & $-0,23 a b$ & $-0,25$ \\
\hline & 80 & $10,56 \pm 1,06$ & $10,99 \pm 0,98$ & $0,43 \mathrm{a}$ & $9,51 \pm 1,14$ & $9,53 \pm 0,49$ & $0,02 \mathrm{ab}$ & $8,58 \pm 0,40$ & $8,3 \pm 0,71$ & $-0,29 a b$ & 0,05 \\
\hline & 160 & $9,04 \pm 0,84$ & $9,16 \pm 0,98$ & $0,12 \mathrm{a}$ & $10,05 \pm 0,63$ & $10,05 \pm 0,16$ & $0 \mathrm{~b}$ & $9,5 \pm 0,36$ & $9,28 \pm 0,21$ & $-0,22 \mathrm{a}$ & $-0,03$ \\
\hline & Rataan & & & 0,08 & & & $-0,06$ & & & $-0,24$ & \\
\hline
\end{tabular}

Keterangan : Sb: Sebelum; St: Setelah. Huruf berbeda pada baris atau kolom yang sama menunjukkan berbeda nyata $(\mathrm{P}<0,05)$. 
transportasi dengan level pemberian $\mathrm{ZnSO}_{4}$ berbeda.

Kadar hemoglobin ayam broiler sebelum transportasi berkisar 8,58-10,94 g/dL. Selisih kadar hemoglobin darah ayam semakin menurun seiring lama waktu tempuh transportasi dengan kisaran 8,30-10,99 g/dL. Penurunan kadar hemoglobin pada kelompok ayam tanpa suplementasi $\mathrm{ZnSO}_{4}$, terjadi setelah waktu tempuh 1 jam dan merupakan penurunan dengan angka tertinggi. Sementara pada kelompok ayam dengan suplementasi $\mathrm{ZnSO}_{4}$, kadar hemoglobin mulai menurun setelah waktu tempuh 3 jam.

Kadar hemoglobin darah pada kelompok ayam dengan pemberian $\mathrm{ZnSO}_{4}$ mampu dipertahankan hingga waktu tempuh 2 jam. Namun seiring lama waktu tempuh transportasi yang semakin panjang disertai kurangnya asupan nutrisi dapat memicu kelelahan pada ayam. Dampak stres akibat transportasi mulai terlihat pada kadar hemoglobin yang menurun setelah waktu tempuh 3 jam.

Afinitas oksigen saat ayam tercekam stres diduga meningkat dengan pemberian $\mathrm{ZnSO}_{4}$ setelah waktu tempuh 1 dan 2 jam untuk mendukung peredaran oksigen melalui darah ke jaringan yang membutuhkan. Aktivitas $\mathrm{Zn}$ dalam berikatan dengan hemoglobin dapat meningkatkan afinitas oksigen (Rifkind dan Heim 1997). Penurunan kadar hemoglobin setelah waktu tempuh 3 jam diduga karena kebutuhan energi yang tidak tercukupi seiring lama waktu tempuh transportasi.

\section{Indeks Eritrosit}

Pendugaan terhadap gejala anemia dilakukan dengan menganalisis indeks eritrosit yaitu selisih nilai $\mathrm{MCH}$, MCHC, dan MCV. Anemia merupakan suatu keadaan rendahnya jumlah eritrosit dan kadar hemoglobin atau nilai hematokrit (Smeltzer dan Bare 2000). Setelah dilakukan analisis statistik terhadap peubah indeks eritrosit (selisih nilai $\mathrm{MCH}, \mathrm{MCHC}$, dan $\mathrm{MCV}$ ), tidak ditemukan interaksi antara lama waktu tempuh transportasi dengan level pemberian $\mathrm{ZnSO}_{4}$ berbeda. Peubah indeks eritrosit tidak menunjukkan perbedaan pada ayam dengan waktu tempuh dan level pemberian $\mathrm{ZnSO}_{4}$ berbeda. Hasil analisis disajikan dalam Tabel 2.

\section{Selisih Nilai MCH}

Nilai mean corpuscular hemoglobin $(\mathrm{MCH})$ adalah rataan kadar hemoglobin dari setiap satuan eritrosit dengan nilai normal berkisar antara 32,0-43,9 pg (Samour 2015). Nilai $\mathrm{MCH}$ pada penelitian ini tergolong normal untuk sebagian besar kombinasi perlakuan, baik sebelum transportasi $(32,13-38,40 \mathrm{pg})$ maupun setelah transportasi (31,83-40,40 pg). Sarma (1990) menyatakan bahwa nilai $\mathrm{MCH}$ dapat menjadi acuan terhadap gejala anemia dan umumnya berbanding lurus dengan nilai jumlah eritrosit. Nilai MCH yang pada penelitian ini sejalan dengan parameter jumlah eritrosit yang termasuk kategori normal.

\section{Selisih Nilai MCHC}

MCHC (mean corpuscular hemoglobin concentration) dapat diartikan sebagai bobot hemoglobin per liter volume darah (Sarma 1990) dengan nilai normal pada rentang 30,2-36,2 g/L (Samour 2015). Sebagian besar nilai MCHC pada penelitian ini berada diatas kisaran angka normal baik sebelum transportasi $(35,91-42,96 \mathrm{~g} / \mathrm{L})$ maupun setelah transportasi $(34,69-41,50 \mathrm{~g} / \mathrm{L})$. Tingginya nilai MCHC menunjukkan tidak terjadi defisiensi mineral yang dibutuhkan dalam sintesis eritrosit seperti zat besi dan $\mathrm{Zn}$ (Samour 2015). Nilai MCHC mengalami penurunan pada kelompok ayam tanpa pemberian $\mathrm{ZnSO}_{4}$ sejak waktu tempuh 1 jam sementara pada kelompok ayam dengan pemberian $\mathrm{ZnSO}_{4}$ (baik 80 maupun 160 ppm) baru menunjukkan penurunan setelah waktu tempuh 3 jam. Level pemberian $\mathrm{ZnSO}_{4} 160$ ppm menunjukkan penurunan nilai MCHC yang lebih rendah dibandingkan level $80 \mathrm{ppm}$. Diduga pemberian $\mathrm{ZnSO}_{4}$ sebagai salah satu mikro mineral mampu mendukung pembentukan hemoglobin dilihat dari nilai $\mathrm{MCH}$ dan MCHC pada penelitian ini.

\section{Selisih Nilai MCV}

MCV (mean corpuscular volume) digunakan untuk mengetahui ukuran dari eristrosit (Sarma 1990) dengan rentang angka normal ialah 104-135 fl (Samour 2015). Nilai MCV secara umum pada sebelum transportasi $(81,85-105,7$

Tabel 2. Indeks eritrosit ayam broiler dengan waktu tempuh transportasi dan level pemberian ZnSO4 berbeda

\begin{tabular}{|c|c|c|c|c|c|c|c|c|c|c|c|}
\hline \multirow[t]{3}{*}{ Peubah } & \multirow{3}{*}{$\begin{array}{l}\mathrm{ZnSO}_{4} \\
(\mathrm{ppm})\end{array}$} & \multicolumn{9}{|c|}{ Waktu Tempuh } & \multirow{3}{*}{$\begin{array}{c}\text { Rataan } \\
\Delta\end{array}$} \\
\hline & & \multicolumn{3}{|c|}{$1 \mathrm{Jam}$} & \multicolumn{3}{|c|}{2 Jam } & \multicolumn{3}{|c|}{3 Jam } & \\
\hline & & $\mathrm{Sb}$ & $\mathrm{St}$ & $\Delta$ & $\mathrm{Sb}$ & St & $\Delta$ & $\mathrm{Sb}$ & St & $\Delta$ & \\
\hline \multirow[t]{4}{*}{ MCH (pg) } & 0 & $37.67 \pm 2.56$ & $37.35 \pm 2.4$ & $-0,32$ & $34.52 \pm 3.86$ & $38.11 \pm 6.07$ & 3,59 & $37.72 \pm 5.92$ & $38.86 \pm 6.32$ & 1,14 & 1,47 \\
\hline & 80 & $38.11 \pm 3.28$ & $38.6 \pm 1.3$ & 0,49 & $32.36 \pm 5.81$ & $33.6 \pm 3.55$ & 1,24 & $32.13 \pm 3.22$ & $31.83 \pm 1.09$ & $-0,3$ & 0,48 \\
\hline & 160 & $32.78 \pm 2.7$ & $32.27 \pm 1.62$ & $-0,51$ & $38.4 \pm 3.4$ & $40.4 \pm 5.4$ & 2 & $33.63 \pm 1.15$ & $32.26 \pm 1.02$ & $-1,38$ & 0,04 \\
\hline & Rataan & & & $-0,11$ & & & 2,28 & & & $-0,18$ & \\
\hline \multirow{4}{*}{$\begin{array}{l}\text { MCHC } \\
(\mathrm{g} / \mathrm{L})\end{array}$} & 0 & $42.09 \pm 4.83$ & $41.5 \pm 4.02$ & $-0,58$ & $36.48 \pm 1.99$ & $37.91 \pm 2.25$ & 1,42 & $42.96 \pm 10.58$ & $41.2 \pm 2.21$ & $-1,75$ & $-0,3$ \\
\hline & 80 & $39.04 \pm 2.78$ & $40.99 \pm 2.21$ & 1,95 & $35.91 \pm 2.98$ & $36.3 \pm 0.58$ & 0,39 & $37.42 \pm 5.34$ & $34.69 \pm 0.19$ & $-2,73$ & $-0,13$ \\
\hline & 160 & $36.55 \pm 3.76$ & $37.05 \pm 1.25$ & 0,5 & $36.59 \pm 3.86$ & $36.96 \pm 5.27$ & 0,37 & $41.33 \pm 2.48$ & $40.53 \pm 1.78$ & $-0,8$ & 0,03 \\
\hline & Rataan & & & 0,62 & & & 0,73 & & & $-1,76$ & \\
\hline \multirow[t]{4}{*}{$\operatorname{MCV}(f l)$} & 0 & $89.84 \pm 4.45$ & $90.25 \pm 5.07$ & 0,41 & $94.61 \pm 9.01$ & $100.48 \pm 13.71$ & 5,87 & $89.05 \pm 8.28$ & $93.96 \pm 10.04$ & 4,91 & 3,73 \\
\hline & 80 & $97.54 \pm 2.46$ & $94.23 \pm 2.39$ & $-3,32$ & $89.67 \pm 8.64$ & $92.48 \pm 8.51$ & 2,81 & $85.3 \pm 2.63$ & $91.7 \pm 2.63$ & 6,41 & 1,97 \\
\hline & 160 & $89.89 \pm 5.26$ & $87.17 \pm 5.52$ & $-2,72$ & $105.07 \pm 1.97$ & $109.8 \pm 10.55$ & 4,72 & $81.85 \pm 7.68$ & $79.63 \pm 0.99$ & $-2,22$ & $-0,07$ \\
\hline & Rataan & & & $-1,88$ & & & 4,47 & & & 3,03 & \\
\hline
\end{tabular}

Keterangan: Sb: Sebelum; St: Setelah. 
fl) maupun setelah transportasi $(79,63-109,80 \mathrm{fl})$ berada dalam kondisi rendah kecuali $\mathrm{W}_{2} \mathrm{Z}_{160}$. Pada $\mathrm{W}_{2} \mathrm{Z}_{160}$ berada pada kondisi normal karena memiliki kadar hemoglobin yang relatif stabil di dalam eritrosit. Rendahnya nilai MCV menunjukkan indikasi terjadinya gangguan terhadap sintesis eritrosit yang menghasilkan sel berukuran relatif kecil/ retikulosit (Sarma 1990). Kehilangan cairan di dalam tubuh dan asupan nutrisi yang tidak tercukupi dapat mengganggu sintesis eritrosit dan secara tidak langsung mengakibatkan penurunan nilai MCV terutama setelah mengalami proses transportasi. Meskipun terjadi peningkatan nilai MCV pada seluruh kombinasi perlakuan setelah waktu tempuh 2 jam, namun sebagian besar kombinasi perlakuan masih memiliki nilai yang tergolong rendah. Nilai MCV yang rendah dapat menjadi indikasi terjadinya anemia pada kategori mikrositik (Sarma 1990). Peranan $\mathrm{ZnSO}_{4}$ terhadap peningkatan nilai $\mathrm{MCV}$ belum terlihat konsisten namun diduga $\mathrm{Zn}$ berperan dalam peningkatan produksi retikulosit setelah waktu tempuh 2 jam.

\section{KESIMPULAN}

Waktu tempuh selama 1, 2, dan 3 jam telah mengakibatkan perubahan pada nilai hematologi sebagai respon tubuh ayam menghadapi stres transportasi. Perubahan tersebut berupa penurunan pada jumlah eritrosit dan nilai hematokrit serta terindikasi anemia mikrositik berdasarkan nilai MCV yang rendah. Suplementasi $\mathrm{ZnSO}_{4}$ melalui air minum dengan level pemberian 80 dan 160 ppm selama 7 hari sebelum pemotongan diduga mampu mempertahankan kadar hemoglobin dan nilai MCH serta MCHC ayam hingga waktu tempuh transportasi 2 jam.

\section{DAFTAR PUSTAKA}

Bedánová I, Voslárová E, Vecerek V, Pistěková V, Chloupek P. 2006. Effects of Reduction in Floor Space during Crating on Haematological Indices in Broilers. Berl Munch Tierarztl Wochenschr 119(1-2):17-21.

Etim NN, Williams ME, Akpabio U, Offiong EEA. 2013. Haematological Parameters and Factors Affecting Their Values. Agricultural Science Vol. 2(1):37-47.

Hoffbrand AV, Pettit JE. 1996. Kapita Selekta: Hematologi dalam Essential Haematology. Edisi ke-2. Buku Kedokteran EGC, Jakarta.

Kementerian Kesehatan Republik Indonesia. 2011. Pedoman Interpretasi Data Klinik. Kementerian Kesehatan Republik Indonesia, Jakarta.

Nain S, Ling B, Bandy B, Alcorn J, Wojnarowicz C, Laarveld B, Olkowski AA. 2008. The Role of Oxidative Stress in the Development of Congestive Heart Failure in Chicken Genotype Selected for Rapid Growth. Avian Pathology 37(4):367-373.

Rifkind JM, Heim JM. 1997. Interaction of Zinc with Hemoglobin: Binding of Zinc and the Oxygen. Biochemistry Vol. 16(20):4438-4443.

Rosita A, Mushawwir A, Latipudin D. 2015. Status Hematologis (Eritrosit, Hematokrit, dan Hemoglobin) Ayam Petelur Fase Layer Pada Temperature Humidity
Index yang Berbeda. Universitas Padjadjaran Students e-Journal Vol. 4 No. 1.

Samour J. 2015. Diagnostic Value of Hematology in Clinical Avian Medicine. Volume II. Harrison GJ, Lightfoot TL. Spix Publishing, Florida.

Sarma PS. 1990. Red Cell Indices dalam Clinical Methods: The History, Physical, and Laboratory Examinations. $3^{\text {rd }}$ Edition. Walker HJ, Hall WD, Hurst JW. National Center for Biotechnology Information, U.S. National Library of Medicine, Boston.

Sastradipraja D, Sikar SHS, Wijayakusuma R, Ungerer T, Maad A, Nasution H, Suriawinata R, Hamzah R. 1989. Penuntun Praktikum Fisiologi Veteriner. Pusat Antar Universitas Ilmu Hayati. Institut Pertanian Bogor (IPB)-Press, Bogor.

Smeltzer SC, Bare BG. 2000. Brunner and Suddarth's Textbook of Medical Surgical Nursing. $9^{\text {th }}$ Edition. Lippincott Williams \& Williams, Philadelphia.

Sturkie PD, Griminger P. 1976. Blood Physical Characteristics, Formed, Elements, Hemoglobin, and Coagulan in Avian Physiology. $3^{\text {rd }}$ Edition. Springer, New York.

Sunder GS, Kumar ChV, Panda AK, Raju MVLN, Rama Rao SV. 2012. Effect of Supplemental Organic $\mathrm{ZnSO}_{4}$ and $\mathrm{Mn}$ on Broiler Performance, Bone Measures, Tissue Uptake and Immune Response at 35 Days of Age. Curr. Res. Poult. Sci. pp:1-11.

Tadich N, Gallo H, Bustamante H, Schwerter M, van Schaik G. 2005. Effects of Transport and Lairage Time on some Blood Constituents of Friesiean-Cross steers in Chile. Livest. Prod. Sci. 93:223-233.

Tawfeek SS, Hassanin KMA, Youssef IMI. 2014. The Effect of Dietary Supplementation of Some Antioxidants on Performance, Oxidative Stress, and Blood Parameters in Broilers under Natural Summer Conditions. J. World's Poultry Res. 4(1):10-19.

Virden WS, Lilburn MS, Thaxton JP, Corzo A, Hoehler D, Kidd MT. 2007. The Effect of Corticosterone-Induced Stress on Amino Acid Digestibility in Ross Broilers. Poult. Sci. 86:338-342.

Vo KV, Boonc MA, Johnston WE. 1978. Effects of Three Lifetime Ambient Temperatures on Growth, Feed, and Water Consumption and Various Blood Components in Male and Female Leghorn Chickens. Poultry Science 57:798-803.

Wardhana AH, Kencanawati E, Nurmawati, Rahmaweni, Jatmiko CB. 2001. Pengaruh Pemberian Sediaan Patikan Kebo (Euphorbia Hirta L) terhadap Jumlah Eritrosit, Kadar Hemoglobin, dan Nilai Hematokrit pada Ayam yang Diinfeksi dengan Eimeria tenella. Jurnal Ilmu Ternak dan Veteriner Vol. 6 No. 2 Th. 2001.

Wennecke G. 2004. A Review of Different Analytical Methods. Acute Care Testing. www.acutecaretesting. org [27 September 2017]. 